\title{
Karakterisasi Permukaan Pada Aluminium Anodized- Dyed dengan Pewarna Alami Kunyit
}

\author{
Ahmad Muslim $^{\mathrm{a}}$, Aris Widyo Nugroho ${ }^{\mathrm{b}}$ \\ ${ }^{a, b}$ Program Studi Teknik Mesin, Fakultas Teknik, Universitas Muhammadiyah Yogyakarta \\ Jalan Brawijaya, Tamantirto, Kasihan, Bantul 55183 \\ Telp. (0274) 387656 / (0274) 387646 \\ e-mail: ahmadmuslim18@gmail.com ${ }^{\mathrm{a}}$, ariswidyo.nugroho@umy.ac.id ${ }^{\mathrm{b}}$
}

\begin{abstract}
Dyeing on anodizing process can be done with chemical or natural dyes. Indonesia has a variety of useful plants as a natural dye, one of which is turmeric. The purpose of this research is to know the effect of turmeric dye concentration variation on color brightness, macro structure, surface roughness, oxide layer thickness and wear rate on aluminum anodizing result. Aluminum plate with 1.5 $\mathrm{mm}$ thick was cut with size of $50 \times 30 \mathrm{~mm}$. The plate was anodized process with 2 ampere of current, 12 volt of voltage for 30 minutes. Dyeing was carried out using commercially available turmeric powder. The dyeing process used variations in concentration of 10,20 and $30 \mathrm{gram}$ per liter of water at temperature of $90-97^{\circ} \mathrm{C}$ for 30 minutes. The coloring results were tested for color brightness by image analysis software, macro structure test and oxide layer thickness using optical microscope and surface roughness test using roughness tester and wear test with Ogoshi method. Test results showed the effect of turmeric concentration variation concentration on color brightness, macro structure, surface roughness and wear rate. The highest color brightness (RGB) is obtained on a variation of turmeric concentration of $10 \mathrm{gram} /$ liter. The surface macro structure showed the existence of homogeneous pores. The most uniform colored staining is obtained on the variation of turmeric concentration of 30 grams / liter. Whilst the highest surface roughness was found on aluminum which had been anodized with variation of turmeric concentration of $30 \mathrm{gram} /$ liter with the value of $1,344 \mu \mathrm{m}$, its wear value presents the lowest of $2.07 \times 10-10 \mathrm{~mm} 2 / \mathrm{kg}$. The concentration variation of the dye solution did not affect the thickness of the resulting oxide layer.
\end{abstract}

Keywords: concentration, natural dye, turmeric, anodizing, aluminum

\section{Pendahuluan}

Anodizing merupakan proses elektrokimia sederhana yang mulai dikembangkan pada abad ke-20 dengan membentuk sebuah lapisan pelindung aluminium oksida pada permukaan aluminium [1]. Proses anodizing pada aluminium dilakukan untuk meningkatkan sifat mekanis maupun estetis dari permukaan. Proses tersebut menghasilkan lapisan oksida tipis yang berpori yang keras dan tahan korosi. Pori ini dapat dimanfaatkan untuk memberikan pewarnaan yang beragam bila diisi zat warna. Pewarnaan pada proses anodizing dapat dilakukan dengan pewarna kimia maupun pewarna alami.

Indonesia memiliki beragam tanaman yang bermanfaat sebagai pewarna alternatif. Tanaman yang sering digunakan untuk pewarna alternatif adalah daun suji, buah bit, bunga telang, bunga sepatu, rimpang kunyit dan masih banyak lagi. Kurkumin dari kunyit, merupakan alternatif yang dapat digunakan, karena selain harganya murah, jumlahnya juga melimpah, dan aman bagi lingkungan. Pemanfaatan zat pewarna alami dapat mengurangi resiko terhadap kerusakan lingkungan. Zat warna kurkumin (diferuloylmethane) merupakan komponen aktif dari kunyit yang berperan untuk warna kuning, dan terdiri dari kurkumin I, kurkumin II (demetoksikurkumin) dan kurkumin III (bis-demetoksikurkumin). Senyawa tersebut berada dalam bentuk kesetimbangan antara bentuk keto dan enol [2]. 
Dalam melakukan proses pewarnaan alami dilakukan pewarnaan pada aluminium dengan proses anodizing menggunakan bahan dari daun teh sebagai pewarna [3]. Warna yang dihasilkan juga sangat tergantung dari waktu pencelupan dan kepekatan larutan teh yang digunakan. Teh hitam yang digunakan menghasilkan warna kuning keemasan hingga kuning kecoklatan. Semakin tinggi konsentrasi yang digunakan maka menghasilkan warna yang semakin gelap. Sementara itu, penelitian juga dilakukan dengan melakukan pewarnaan aluminium dengan proses anodizing menggunakan bahan pewarna dari daun pandan wangi [4]. Warna yang dihasilkan dari daun pandan wangi adalah warna hijau. Hasil anodizing tergantung dari waktu pencelupan dan konsentrasi larutan daun pandan wangi yang digunakan. Hasil yang didapat adalah semakin tinggi konsentrasi larutan konsentrasi yang digunakan maka semakin terang warna yang dihasilkan. Penelitian lain menggunakan ekstraksi dari kulit manggis sebagai pewarna alami dalam proses anodizing. Warna yang dihasilkan dari ekstraksi kulit manggis tersebut mulai dari warna kuning muda sampai kuning kecoklatan. Konsentrasi warna yang semakin tinggi menghasilkan warna yang semakin gelap [5].

Penelitian sebelumnya menggunakan kunyit sebagai pewarna alami pada proses anodizing dengan konsentrasi larutan 5 gram, 10 gram, 15 gram dan 20 gram per liter [6]. Penelitian tersebut menghasilkan warna yang belum seragam dan berbeda-beda. Dari beberapa hasil penelitian di atas menunjukkan konsentrasi larutan pewarna yang digunakan pada proses dyeing sangat mempengaruhi hasil dari kecerahan warna. Namun dari penelitian tersebut belum diketahui sifat mekanisnya. Penelitian ini dilakukan untuk mengetahui pengaruh dyeing dari bahan kunyit terhadap struktur makro permukaan, kekasaran permukaan, ketebalan lapisan oksida, dan laju keausan hasil anodizing.

\section{Metodologi}

Diagram alir penelitian dapat ditunjukkan seperti Gambar 2.1 .

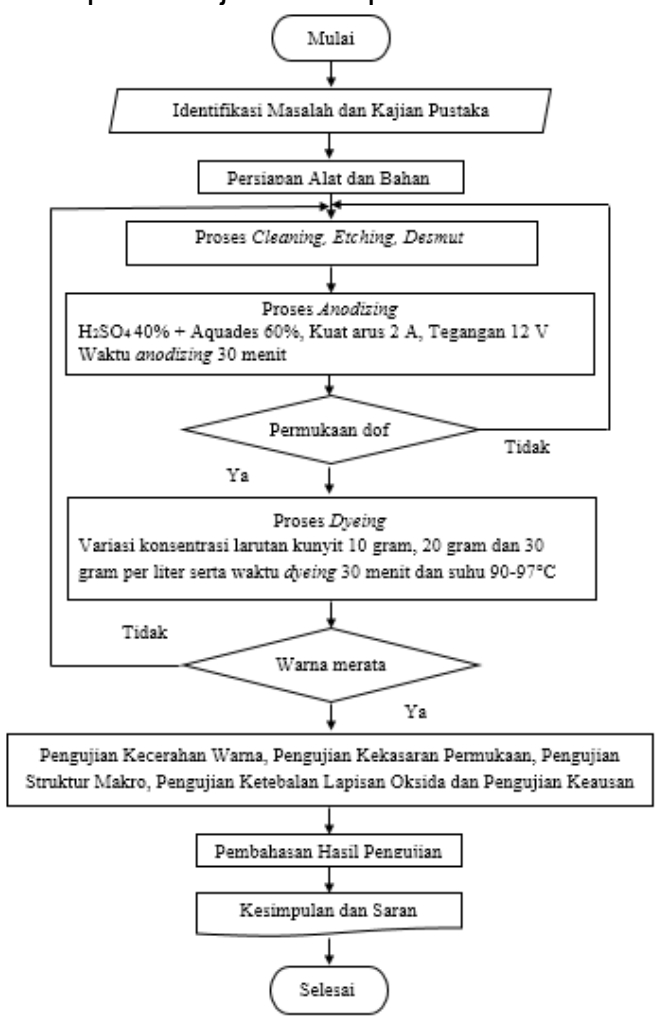

Gambar 2.1 Diagram Alir Penelitian

\subsection{Tahapan Proses Anodizing Aluminium}

Tahapan yang dilakukan pada proses anodizing aluminium antara lain: proses pengamplasan yang bertujuan untuk pembersihan lubang atau kotoran yang terdapat pada 
permukaan spesimen dengan menggunakan kertas amplas. Proses pengamplasan menggunakan amplas logam seri P240, P600, P800 dan P1500 secara berurutan, kemudian spesimen dibilas menggunakan aquades.

Proses cleaning terhadap kotoran yang masih tertinggal pada permukaan spesimen dilakukan menggunakan detergen murni, natrium karbonat $\left(\mathrm{Na}_{2} \mathrm{CO}_{3}\right)$, dengan konsentrasi larutan yang digunakan $10 \mathrm{gram} / \mathrm{liter}$ aquades. Proses ini berlangsung selama lima menit. Setelah proses cleaning selesai kemudian spesimen dibilas menggunakan aquades dengan cara dicelupkan ke dalamnya.

Selanjutnya spesimen diproses etching untuk menghilangkan lapisan oksida pada permukaan aluminium yang tidak dapat dihilangkan pada proses sebelumnya. Bahan soda api $(\mathrm{NaOH})$ digunakan dengan konsentrasi 100 gram/liter aquades. Spesimen dietching selama lima menit. Setelah proses etsa selesai, keudian spesimen dibilas menggunakan aquades dengan cara dicelupkan kedalamnya.

Langkah berikutnya dilakukan proses desmut untuk menghilangkan smut pada permukaan aluminium. Larutan desmut merupakan campuran dari larutan Asam fosfat $\left(\mathrm{H}_{3} \mathrm{PO}_{4}\right) 75 \%$ ditambah Asam sulfat $\left(\mathrm{H}_{2} \mathrm{SO}_{4}\right) 15 \%$ dan Asam asetat $\left(\mathrm{CH}_{3} \mathrm{COOH}\right) 10 \%$. Spesimen dicelupkan selama lima menit, kemudian setelah proses desmut selesai spesimen dibilas menggunakan aquades dengan cara dicelupkan kedalamnya dan spesimen telah siap untuk proses anodizing,

Proses anodizing dilakukan dengan cara spesimen dicelupkan ke dalam box plastik berisi larutan asam sulfat $\left(\mathrm{H}_{2} \mathrm{SO}_{4}\right)$ yang sudah dicampur dengan aquades dengan konsentrasi larutan sebesar $400 \mathrm{ml}$ asam sulfat $\left(\mathrm{H}_{2} \mathrm{SO}_{4}\right)$ dan $600 \mathrm{ml}$ aquades dan suhunya tercatat $30^{\circ} \mathrm{C}-40^{\circ} \mathrm{C}$. Pada proses anodisasi spesimen bertindak sebagai anoda $(+)$ dan aluminium penghantar sebagi katoda (-). Tegangan yang dipakai pada proses ini sebesar 12 Volt dan kuat arusnya sebesar 2 ampere. Waktu proses anodizin selama 30 menit. Setelah proses anodic oxidation selesai, selanjutnya dibilas menggunakan aquades sebelum dilanjutkan ke proses dieying.

Proses dyeing. Seletah lapisan oksida baru terbentuk melalui proses anodisasi, selanjutnya proses pewarnaan. Proses ini menggunakan kunyit bubuk sebagai bahan dasarnya. Variasi yang digunakan yaitu $10 \mathrm{gram}, 20 \mathrm{gram}$ dan $30 \mathrm{gram}$ per liter aquades. Proses ini bertujuan untuk mengetahui perbedaan pengaruh variasi konsentrasi terhadap sifat fisik aluminium anodizing. Waktu proses dyeing selama 30 menit. Suhu yang tercatat $90^{\circ} \mathrm{C}-97^{\circ} \mathrm{C}$, yaitu proses pada suhu tinggi ini diharapkan pewarna dari kunyit dapat lebih terserap pada permukaan aluminium.

Terakhir adalah proses sealing yang berfungsi menutup pori-pori lapisan oksida yang dihasilkan dari proses anodic oxidation yang masih terbuka dan untuk mencegah pewarna keluar dari pori-pori lapisan oksida atau pudar, pada proses sealing larutan yang digunakan adalah asam asetat $\left(\mathrm{CH}_{3} \mathrm{COOH}\right)$ dengan konsentrasi $5 \mathrm{gr} /$ liter.Pencelupan dilajukan selama 5 menit. Suhu yang tercatat yaitu $55^{\circ} \mathrm{C}-65^{\circ} \mathrm{C}$. Setelah proses sealing selesai, spesimen dibilas dua kali menggunakan aquades dengan cara dicelupkan kedalamnya dan juga disemprot. Hal ini bertujuan untuk menghilangkan residu yang menempel pada proses dyeing.

\subsection{Karakterisasi Hasil Perlakuan}

Sebelum dilakukan perlakuan, specimen diuji komposisi material untuk mengetahui kandungan dan komposisi kimia dari aluminium yang digunakan dalam penelitian ini. Pengujian komposisi logam dilakukan dengan mesin Spectrometer Thermo ARL 3560 OES yang ada di CV Karya Hidup Sentosa Yogyakarta. Ketebalan specimen sebelum dan setelah proses perlakuan diukur dengan menggunakan alat mikrometer sekrup. Selanjutnya dilakukan pengujian kecerahan warna menggunakan software image processing yang tersedia secara komersial.

Pengujian kekasaran permukaan dilaksanakan di Laboratorium Teknik Mesin Universitas Muhammadiyah Yogyakarta dengan menggunakan alat MR 110. Ketebalan lapisan oksida dan struktur mikro dari hasil proses perlakuan diamati dengan menggunakan mikroskop optik merk Olympus model PME3-111B/-312B di Laboratorium Testing Material D-3 Teknik. Pengujian keausan dilakukan dengan metode Ogoshi, menggunakan alat RikenOgoshi's Universal Wear, dimana benda uji memperoleh beban gesek dari cincin yang 
berputar sesuai dengan parameter seperti kecepatan, jarak luncur dan pembebanan. Besarnya jejak permukaan benda uji yang tergesek yang dijadikan dasar penentuan tingkat keausan material.

\section{HASIL DAN PEMBAHASAN}

\subsection{Hasil Anodizing}

Pada percobaan awal teramati bahwa pewarna tidak menempel dengan merata pada permukaan aluminium (Gambar 3.1). Hasil tersebut dipengaruhi beberapa hal seperti penggunaan perasan kunyit dan proses dyeing tidak dipanaskan.

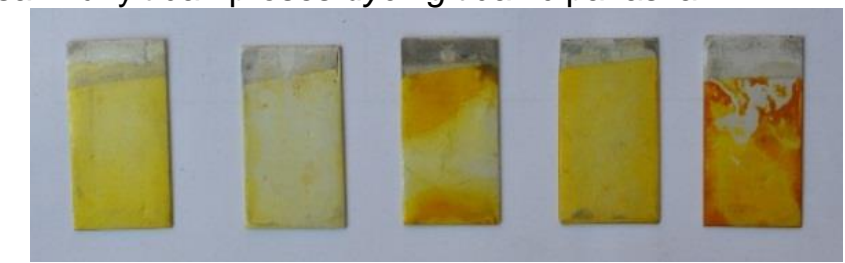

Gambar 3.1 Kegagalan dari proses dyeing pada proses anodizing

Dari kegagalan tersebut metode pewarnaan diganti menggunakan kunyit bubuk dan juga dipanaskan hingga suhu $100^{\circ} \mathrm{C}$ serta diberi aerator. Hasil percobaan menunjukkan adanya lapisan warna yang lebih pekat dan menempel dipermukaan alumunium dengan merata (Gambar 3.2).

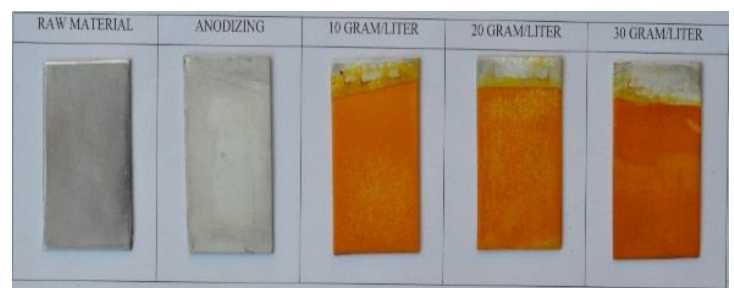

Gambar 3.2 Hasil anodizing menggunakan variasi konsentrasi pewarna kunyit

\subsection{Hasil Pengujian Spectrometer}

Tabel 3.1 menunjukkan hasil pengujian komposisi kimia spesimen aluminium yang digunakan pada penelitian ini.

\begin{tabular}{cc}
\multicolumn{2}{c}{ Tabel 3.1 Komposisi kimia aluminium } \\
\hline Unsur & Komposisi (\%) \\
\hline $\mathrm{Si}$ & 0,13 \\
$\mathrm{Fe}$ & 0,4945 \\
$\mathrm{Cu}$ & 0,097 \\
$\mathrm{Mn}$ & 0,1104 \\
$\mathrm{Mg}$ & 0,1022 \\
$\mathrm{Zn}$ & 0,2135 \\
$\mathrm{Ti}$ & 0,0212 \\
$\mathrm{Cr}$ & 0,0044 \\
$\mathrm{Ni}$ & 0,0000 \\
$\mathrm{~Pb}$ & 0,0244 \\
$\mathrm{Sn}$ & 0,0043 \\
$\mathrm{Al}$ & 98,79
\end{tabular}

Berdasarkan hasil pengujian spectrometer tersebut maka dapat disimpulkan bahwa aluminium yang digunakan dalam penelitian ini adalah aluminium seri 7xxx. Hal tersebut 
dikarenakan unsur pembentuk lain dengan persentase terbesar dalam spesimen adalah Zinc.

\subsection{Hasil Pengukuran Ketebalan Spesimen}

Spesimen yang digunakan terlebih dulu diukur ketebalannya. Hal tersebut, bertujuan untuk mengetahui laju pengurangan yang diakibatkan oleh proses anodizing. Spesimen diukur menggunakan alat mikrometer dial dengan tiga titik pengukuran.

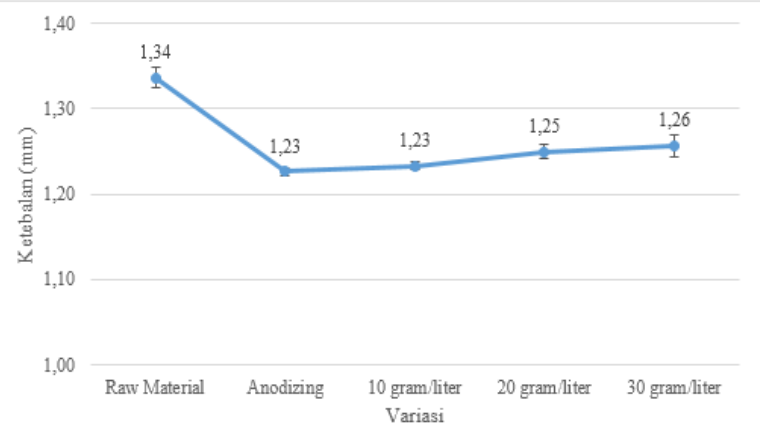

Gambar 3.3 Grafik hubungan antara variasi konsentrasi larutan kunyit terhadap ketabalan spesimen

Gambar 3.3 menunjukkan hasil pengukuran ketebalan spesimen mulai dari raw material yang sudah diamplas, anodizing tanpa pewarna hingga spesimen yang telah dianodizing dengan variasi konsentrasi larutan pewarna kunyit. Hasil pengukuran raw material setelah dirata-rata adalah 1,337 mm, untuk anodizing tanpa pewarna adalah 1,227 $\mathrm{mm}$, untuk variasi konsentrasi larutan kunyit $10 \mathrm{gram} / \mathrm{liter}$ ialah 1,233 $\mathrm{mm}$, untuk variasi konsentrasi larutan kunyit $20 \mathrm{gram} /$ liter $1,250 \mathrm{~mm}$ dan variasi konsentrasi larutan kunyit 30 gram/liter sebesar $1,257 \mathrm{~mm}$.

Spesimen anodizing tanpa pewarnaan lebih tipis daripada raw material disebabkan adanya pengikisan pada saat proses anodizing. Semakin pekat konsentrasi larutan kunyit yang digunakan maka akan semakin tebal spesimen. Hasil pengukuran ketebalan spesimen tersebut yang telah dianodizing dengan variasi konsentrasi larutan pewarna kunyit diduga disebabkan adanya residu yang ikut menempel pada permukaan spesimen.

\subsection{Hasil Pengujian Kecerahan Warna}

Spesimen yang telah dianodizing dengan variasi konsentrasi larutan pewarna kunyit dilakukan pengujian kecerahan warna (RGB) menggunakan Adobe Photoshop Cs6 dimana akan didapatkan data antara hasil visual pada variasi konsentrasi larutan pewarna kunyit 10 gram, 20 gram dan 30 menit per liter. Pengujian dilakukan pada tiga titik yang berbeda. Berikut hasil pengujian kecerahan warna dengan brightness auto level.

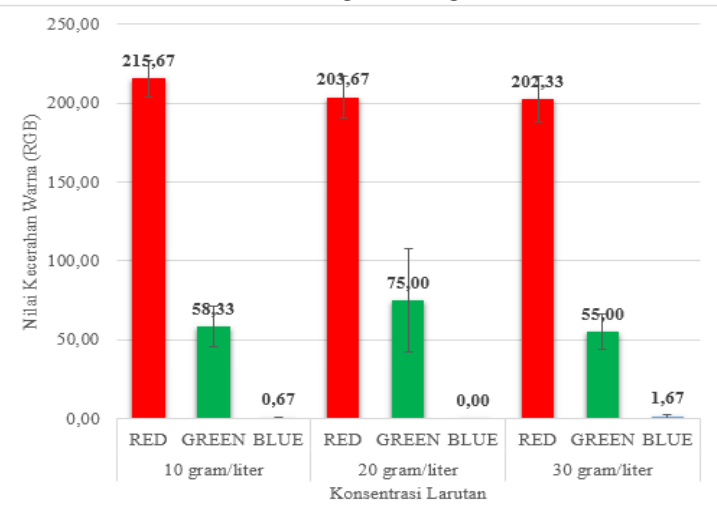

Gambar 3.4 Grafik hubungan antara variasi konsentrasi larutan kunyit terhadap kecerahan warna (RGB)

Gambar 3.4 menunjukkan hasil kecerahan warna (RGB) pada proses anodizing menggunakan pewarna kunyit, 10 gram/liter R 215,67\%, G 58,33\%, B 0,67\%, untuk variasi 
larutan kunyit 20 gram/liter R 203,67\%, G 75\%, B 0\% dan untuk variasi latutan kunyit sebanyak 30 gram/liter R 202,33\%, G 55\% dan B 1,67\%. Grafik tersebut menjelaskan komposisi warna yang dominan adalah warna red tersebut disebabkan oleh pori - pori lapisan oksida yang terisi dengan larutan pewarna kunyit yang digunakan pada penelitian ini. Kemudian, untuk kecerahan tertinggi pada variasi $10 \mathrm{gram} /$ liter sebesar R 215,67\%, G $58,33 \%$, B 0,67\% yang berarti lebih terang daripada variasi $20 \mathrm{gram} / \mathrm{liter}$ dan $30 \mathrm{gram} / \mathrm{liter}$. Jadi, semakin pekat larutan pewarna yang digunakan maka akan semakin gelap warna yang dihasilkan. Hal itu diduga terdapat residu dari bahan pewarna yang ikut menempel pada permukaan aluminium.

Hal ini terbukti secara empirik, hasil penelitian yang menunjukkan semakin pekat konsentrasi larutan pewarna alami yang digunakan, maka hasil warnanya semakin gelap [5]. Warna yang dihasilkan lebih gelap atau terang pada aluminium dimungkinkan oleh panas saat proses sealing, sedangkan penelitian lain menghasilkan lapisan tipis yang kedap dari lingkungan luar dan mencegah zat pewarna keluar dari lapisan anodizing sehingga tidak mudah larut dan tahan lama [7]. Selain itu, faktor yang mempengaruhi kecerahan warna adalah waktu tunggu dari proses anodizing ke proses dyeing yang tidak langsung [6]. Dari analisa diatas dapat disimpulkan bahwa,-semakin pekat konsentrasi larutan kunyit yang digunakan maka akan menghasilkan warna yang semakin gelap dan proses sealing yang menghasilkan lapisan kedap serta waktu tunggu dari proses anodizing ke proses dyeing yang tidak langsung juga mempengaruhi kecerahan warna (RGB).

\subsection{Hasil Pengujian Kekasaran Permukaan}

Proses anodizing yang dilakukan pada aluminium memiliki pengaruh terhadap kekasaran permukaannya. Hasil yang didapat juga berbeda sesuai dengan variasi konsentrasi yang diberikan. Pengujian kekasaran permukaan aluminium menggunakan alat Roughness Tester dengan tiga titik pengujian.

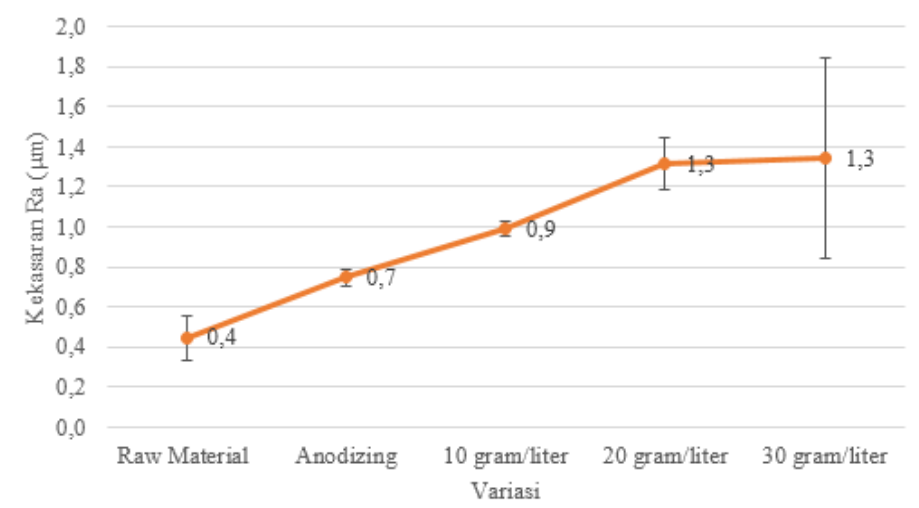

Gambar 3.5 Grafik hubungan antara variasi konsentrasi larutan kunyit terhadap kekasaran permukaan

Gambar 3.5 menunjukkan hasil kekasaran pada permukaan aluminium didapatkan dari raw material yang sudah diamplas, anodizing tanpa pewarna hingga spesimen yang telah dianodizing dengan variasi konsentrasi larutan pewarna kunyit. Pada raw material yang sudah diamplas didapatkan nilai kekasaran 0,447 $\mu \mathrm{m}$, untuk aluminium yang sudah dianodizing tanpa pewarna didapatkan nilai kekasaran $0,747 \mu \mathrm{m}$, untuk aluminium yang telah dianodizing dengan variasi konsentrasi larutan pewarna kunyit 10 gram/liter sebesar $0,991 \mu \mathrm{m}$, untuk aluminium yang telah dianodizing dengan variasi konsentrasi larutan pewarna kunyit 20 gram/liter sebesar $1,312 \mu \mathrm{m}$ dan untuk aluminium yang telah dianodizing dengan variasi konsentrasi larutan pewarna kunyit 30 gram/liter sebesar 1,344 $\mu \mathrm{m}$.

Hasil kekasaran tertinggi terdapat pada aluminium yang telah dianodizing dengan variasi konsentrasi larutan pewarna kunyit 30 gram/liter yang berarti lebih kasar daripada variasi $10 \mathrm{gram} /$ liter dan $20 \mathrm{gram} / \mathrm{liter}$ serta hasil kekasaran yang paling halus terdapat pada raw material yang sudah diamplas. Hal tersebut diakibatkan karena pada raw material sudah dihaluskan permukaannya. Semakin pekat konsentrasi larutan kunyit yang digunakan maka akan semakin kasar permukaan aluminium. Hal tersebut diduga karena adanya residu yang 
menempel pada saat proses pewarnaan dan tidak dapat terserap dengan baik oleh aluminium tersebut.

\subsection{Hasil Pengujian Struktur Makro}

Pengujian ini dilakukan untuk mengetahui struktur permukaan makro aluminium sebelum dan sesudah diproses anodizing menggunakan variasi konsentrasi larutan pewarna kunyit. Foto struktur makro permukaan aluminium didapatkan dari raw material anodizing tanpa pewarna hingga spesimen yang telah dianodizing dengan variasi konsentrasi larutan pewarna kunyit. Perbesaran yang dilakukan sebesar 50 kali.
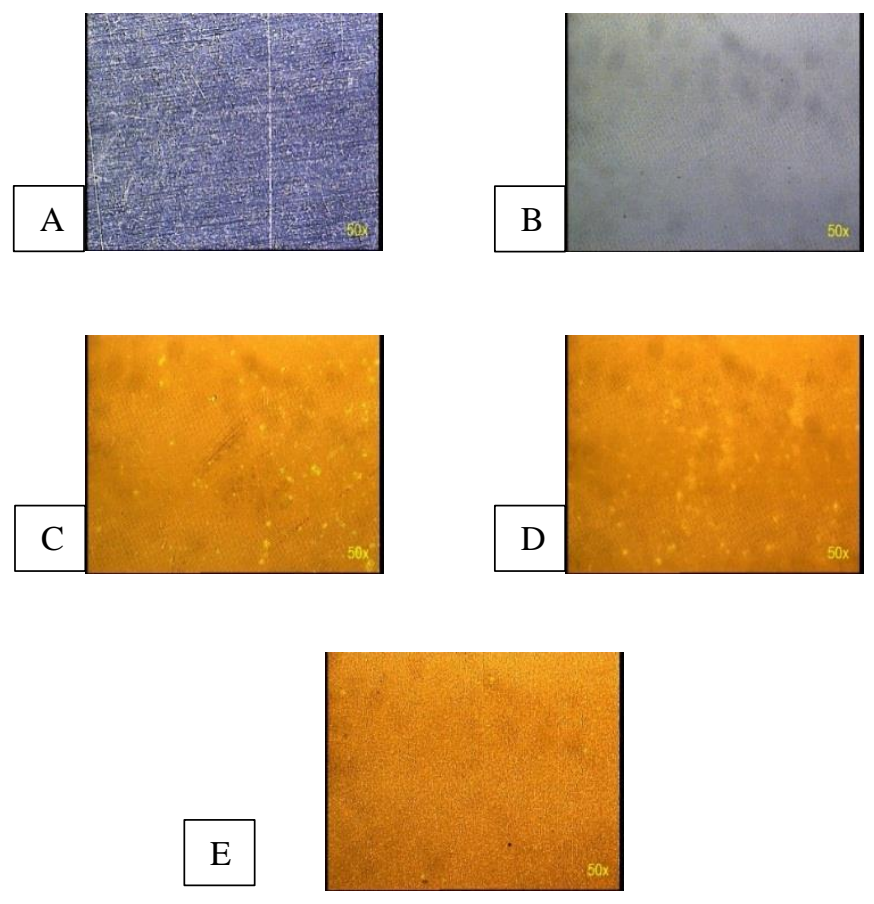

Gambar 3.6 Permukaan aluminium (A) tanpa perlakuan, (B) anodized, (C) anodized dan dyed konsetrasi kunyit 10 gram/liter, (D) 20 gram/liter dan (E) $30 \mathrm{gram} / \mathrm{liter}$

Gambar 3.6 A menunjukkan pengamatan struktur makro permukaan raw material aluminium sebelum diproses anodizing. Dari hasil pengamatan masih menampilkan bekas goresan pada permukaan aluminium. Permukaan aluminium yang telah dianodizing dengan lama waktu 30 menit dan kuat arus listrik sebesar 2 ampere menunjukkan bahwa pori-pori lapisan oksida baru telah terbentuk, telah menghasilkan pori-pori yang homogen (gambar 3.6 B). Setelah proses dyeing engan konsentrasi larutan pewarna kunyit 10 gram/liter selama 30 menit terlihat pewarna telah meresap ke dalam pori-pori lapisan oksida dan warna yang dihasilkan kuning terang (gambar 3.6 C). Dengan kenaikan konsentrasi kunyit, warna yang dihasilkan semakin menjadi kuning tua namun belum seragam (gambar D) dan menjadi kuning kejinggaan dan lebih homogen pada konsentrasi 30 gram/liter selama 30 menit (gambar 3.6 E) .

\subsection{Hasil Pengujian Ketebalan Lapisan Oksida}

Pengujian ini dilakukan bertujuan untuk mengetahui tebal lapisan oksida yang terbentuk sebelum dan sesudah diproses anodizing menggunakan variasi konsentrasi larutan pewarna kunyit. Foto mikro ketebalan lapisan oksida aluminium didapatkan dari raw material, anodizing tanpa pewarna hingga spesimen yang telah dianodizing dengan variasi konsentrasi larutan pewarna kunyit. Agar memudahkan pada saat proses pengamatan foto mikro ketebalan lapisan oksida aluminium, dilakukan proses mounting pada specimen. Perbesaran sebesar 50 kali, dengan setiap strip adalah $10 \mu \mathrm{m}$ (Gambar 3.7) 


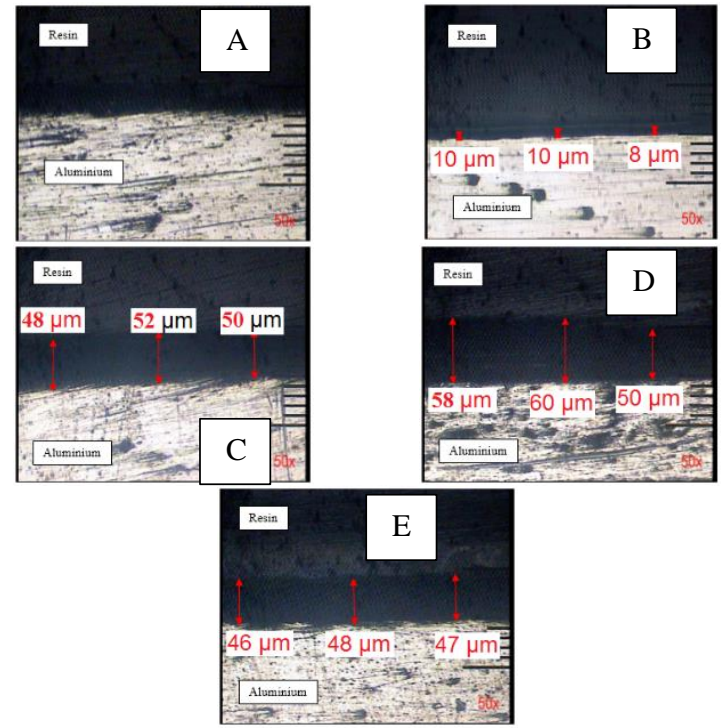

3.7 Foto ketebalan lapisan oksida (A) tanpa perlakuan, (B) anodized, (C) anodized dan dyed konsetrasi kunyit $10 \mathrm{gram} / \mathrm{liter}$, (D) $20 \mathrm{gram} / \mathrm{liter}$ dan (E) $30 \mathrm{gram} / \mathrm{liter}$

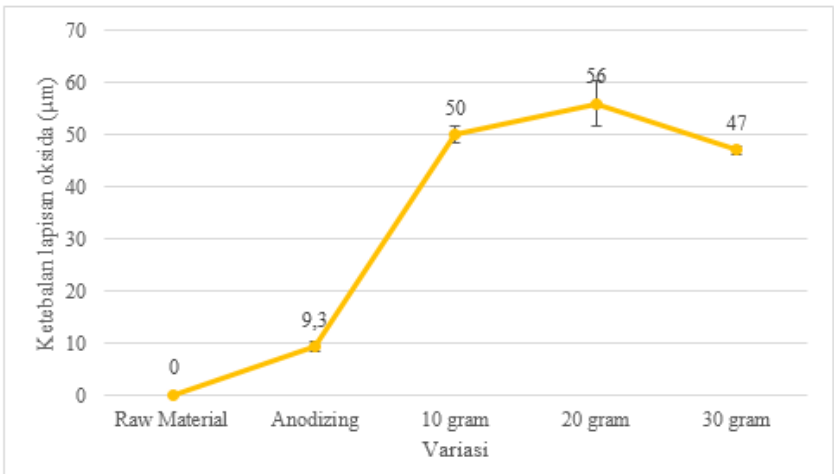

Gambar 3.8 Grafik hubungan antara variasi konsentrasi larutan terhadap ketebalan lapisan oksida

Gambar 3.8 menunjukkan hubungan antara variasi konsentrasi larutan terhadap ketebalan lapisan oksida pada permukaan aluminium yang telah dianodizing, pada raw material tidak terlihat adanya lapisan oksida karena raw material yang diuji adalah material yang telah diamplas jadi lapisan oksidanya sudah hilang, untuk anodizing tanpa pewarnaan sebesar 9,3 $\mu \mathrm{m}$, untuk aluminium yang telah dianodizing dengan variasi konsentrasi larutan pewarna kunyit 10 gram/liter sebesar $50 \mu \mathrm{m}$, untuk aluminium yang telah dianodizing dengan variasi konsentrasi larutan pewarna kunyit 20 gram/liter sebesar $56 \mu \mathrm{m}$ dan untuk aluminium yang telah dianodizing dengan variasi konsentrasi larutan pewarna kunyit 30 gram/liter sebesar $47 \mu \mathrm{m}$.

Variasi konsentrasi larutan pewarna tidak berpengaruh terhadap ketebalan lapisan oksida yang dihasilkan. Lapisan oksida dihasilkan oleh dipengaruhi oleh temperatur, kuat arus listrik, voltase, konsentrasi larutan dan waktu pencelupan pada larutan elektrolit.

\subsection{Hasil Pengujian Keausan Ogoshi}

Setelah dilakukan pengujian keausan pada spesimen raw material anodizing tanpa pewarna hingga spesimen yang telah dianodizing dengan variasi konsentrasi larutan pewarna kunyit dengan menggunakan mesin uji Ogoshi High Speed Universal Wear Testing Machine type OAT-U dengan lebar piringan $3 \mathrm{~mm}$, jari-jari pengaus $14 \mathrm{~mm}$, beban tekan pengaus $2,12 \mathrm{~kg}$, jarak tempuh pengausan $66,6 \mathrm{~m}$ dan waktu selama 60 detik. 


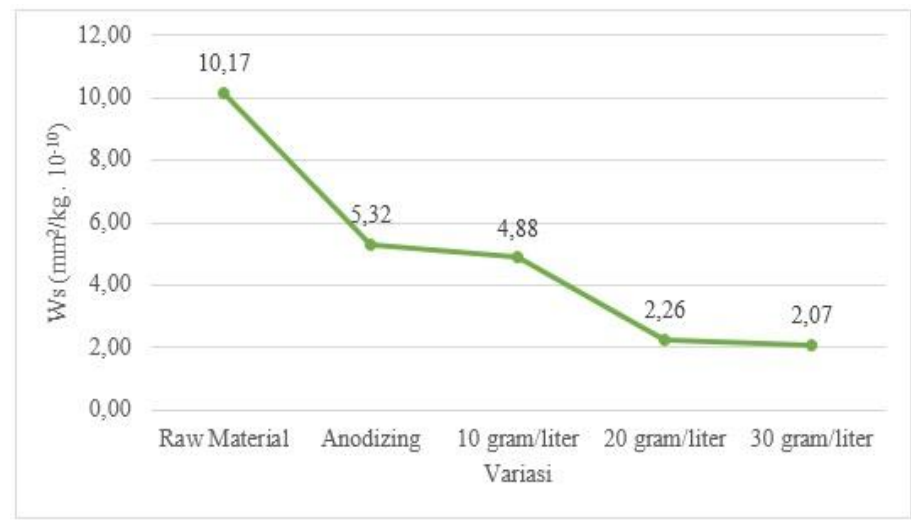

Gambar 3.9 Grafik hubungan antara variasi konsentrasi larutan kunyit terhadap keausan permukaan

Untuk raw material sebesar $10,17 \times 10^{-10} \mathrm{~mm}^{2} / \mathrm{kg}$, untuk aluminium anodizing tanpa pewarnaan memiliki nilai $5,32 \times 10^{-10} \mathrm{~mm}^{2} / \mathrm{kg}$, selanjutnya variasi konsentrasi larutan pewarna kunyit 10 gram/liter sebesar $4,4,88 \times 10^{-10} \mathrm{~mm}^{2} / \mathrm{kg}$, begitu juga untuk variasi konsentrasi larutan pewarna kunyit $20 \mathrm{gram} /$ iter sebesar $2,26 \times 10^{-10} \mathrm{~mm}^{2} / \mathrm{kg}$ dan untuk variasi konsentrasi larutan pewarna kunyit sebanyak $30 \mathrm{gram} /$ liter sebesar $2,07 \times 10^{-10}$ $\mathrm{mm}^{2} / \mathrm{kg}$. Dari gambar 3.9, spesimen yang mengalami keausan paling tinggi yaitu raw material aluminium dengan nilai $10,17 \times 10^{-10} \mathrm{~mm}^{2} / \mathrm{kg}$, sedangkan keausan paling rendah adalah variasi konsentrasi larutan pewarna kunyit 30 gram/liter sebesar $2,07 \times 10^{-10} \mathrm{~mm}^{2} / \mathrm{kg}$. $\mathrm{Hal}$ itu disebabkan adanya residu yang menempel, jadi yang tergesek adalah residu yang menempel pada permukaan spesimen. Jadi, semakin tinggi konsentrasi larutan kunyit yang digunakan maka akan semakin meningkat nilai ketahanan ausnya.

\section{KESIMPULAN}

Dari penelitian, analisa dan pembahasan yang telah dilakukan pada pengaruh konsentrasi larutan kunyit pada proses anodizing, maka dapat disimpulkan sebagai berikut:

1. Kecerahan warna (RGB) tertinggi didapat pada variasi $10 \mathrm{gram} /$ liter sebesar $R$ $215,67 \%$, G 58,33\%, B 0,67\% yang berarti lebih terang daripada variasi 20 gram/liter dan $30 \mathrm{gram} / \mathrm{liter}$. Jadi semakin tinggi konsentrasi larutan pewarna yang digunakan maka akan semakin gelap warna yang dihasilkan.

2. Hasil kekasaran tertinggi terdapat pada aluminium yang telah dianodizing dengan variasi konsentrasi larutan pewarna kunyit $30 \mathrm{gram} / \mathrm{liter}$ yang berarti lebih kasar daripada variasi $10 \mathrm{gram} / \mathrm{liter}$ dan $20 \mathrm{gram} / \mathrm{liter}$ serta hasil kekasaran yang paling halus terdapat pada raw material yang sudah diamplas. Jadi semakin tinggi konsentrasi larutan pewarna yang digunakan maka akan semakin kasar permukaan yang dihasilkan.

3. Struktur makro permukaan telah menghasilkan pori-pori yang homogen, pada pewarnaan paling merata didapat pada variasi larutan kunyit 30 gram/liter dan warna yang dihasilkan kuning kejinggan.

4. Variasi konsentrasi larutan pewarna tidak berpengaruh terhadap ketebalan lapisan oksida yang dihasilkan. Lapisan oksida dihasilkan oleh dipengaruhi oleh temperatur, kuat arus listrik, voltase, konsentrasi larutan dan waktu pencelupan pada larutan elektrolit.

5. Spesimen yang mengalami keausan paling tinggi yaitu raw material aluminium dengan nilai $10,17 \times 10^{-10} \mathrm{~mm}^{2} / \mathrm{kg}$, sedangkan keausan paling rendah adalah variasi konsentrasi larutan pewarna kunyit $30 \mathrm{gram} /$ liter sebesar $2,07 \times 10^{-10} \mathrm{~mm}^{2} / \mathrm{kg}$. Maka dapat disimpulkan bahwa semakin tinggi konsentrasi larutan kunyit yang digunakan maka akan semakin meningkat nilai ketahanan ausnya. 


\section{Daftar Pustaka}

[1] ESTAL. Aluminium Anodising. European association for Surface Treatment of Aluminium. 2015: 1-3.

[2] SEAFAST Center. "Kuning Kunyit'. Pewarna Alami untuk Pangan. 2012:51-57.

[3] Aminnudin; Wahono; Suprayitno. "Penggunaan Teh Untuk Dyeing pada Proses Dekoratif pada Aluminium dengan Proses Anodizing, sebagai Bahan Alternatif yang Ramah Lingkungan". Malang: Lembaga Penelitian UM. 2006.

[4] Rudiyanto, Eddy, 2012. "Kajian Pewarna Daun Pandan Wangi pada Proses Pencelupan Komponen Otomotif'. Jurnal Teknik Mesin. Malang: Universitas Negeri Malang. 2012; 20(1): 35-41

[5] Ngatin, A dan Mulyono, E.W.S. "Ekstraksi Zat Warna dari Kulit Manggis dan Pemanfaatannya untuk Pewarna Logam Aluminium Hasil Anodisasi" dalam IRWNS. Bandung: Politeknik Negeri Bandung. 2013: 268-272.

[6] Anggara, A.D, dkk. "Penggunaan Kunyit sebagai Alternatif Pewarnaan pada Anodising Aluminium yang Ramah Lingkungan" PKM. Malang: Universitas Negeri Malang. 2010.

[7] Canning, W. "The Canning Handbook on Electroplating". Birmingham: W. Canning Limited. 1978. 